\title{
Effect of Different Planting Pattern on Total Dry Matter Production and Maize Forage Quality in Maize (Zea Mays) and Cowpea (Vigna Sinensis) Intercropped As Whole-Crop Forage
}

\author{
${ }^{1}$ Abdulraheem Mukhtar Iderawumi; ${ }^{2}$ Ojeniyi Steven Olusola; ${ }^{3}$ Charles, \\ Eneminyene Friday \\ ${ }^{1}$ Department of Agricultural Education, Emmanuel Alayande College of Education, Oyo, Lanlate \\ Campus, P.M.B 001, Lanlate, Oyo State, Nigeria \\ ${ }^{2}$ Department of Crop, Soil and Pest Management Federal University of Technology, Akure \\ ${ }^{3}$ Nigeria Institutes for Oil Palm Research Benin City, Edo State, Nigeria
}

\begin{abstract}
Mixtures of cereals and legumes are used extensively for forage production. Maize (Zea mays) and cowpea (Vigna sinensis) monocultures as well as their mixture in three planting patterns (M1: alternate-row intercrop, M2: within-row intercrop, M3: mixed intercrop) were used to investigate on forage yield as well as the effect of intercropping on maize forage quality. The experiment was carried out as randomized complete block design with three replications. The results showed that intercropping systems had a significant effect on forage dry weight, where dry matter yield was increased by intercropping as compared with maize and cowpea sole crops. It was related with a higher consumption of environmental resources, such as photosynthetically active radiation and soil moisture, by intercropping. Maize forage quality in terms of crude protein was improved by intercropping. It was because of more nitrogen availability for maize in intercropping compared with its sole crop.
\end{abstract}

Keywords: cereal, crude protein, legume, mixed cropping, resource consumption

\section{Introduction}

Maize (Zea mays), which is the third most important cereal crop of the world, is an important dual purpose crop used in human diet and animal feed. Maize has the potential to supply large amounts of energyrich forage for animal diets, and its fodder can safely be fed at all stages of growth without any danger of oxalic acid, prussic acid as in case of sorghum (Dahmardeh et al., 2009). Thus, forage maize has become a major constituent of ruminant rations in recent years, where its inclusion in dairy cow diets improves forage intake, increases animal performance and reduces production costs (Anil et al., 2000; Cusicanqui and Lauer, 1999).

Although maize provides high yield in terms of dry matter, it produces forage with low protein content. However, protein is needed by livestock for growth and milk production. Protein is also needed by rumen bacteria which digest much of the feed for ruminant animals (Ghanbari-Bonjar, 2000). Because of low protein content, maize hay is usually lower than that required to meet satisfactory production levels for many categories of livestock (Lawes and Jones, 1971). Therefore, it is necessary to provide livestock with protein supplements when forage quality is low. The purchase of protein supplements is expensive and results in high feed costs. Cowpea (Vigna sinensis), an annual legume with high level of protein (about twice times more than maize), can be mixed with maize to improve forage protein content of diets and, thus, the costs of high quality forage production can be lowered.

The growth of two or more crop species simultaneously in the same field during a growing season, which is defined as intercropping (Ofori and Stern, 1987), has many advantages over sole cropping. It provides an efficient utilization of environmental resources, reduces risk to the cost of production, provides greater financial stability for farmers, decreases pest damages, suppresses weeds growth more than monocultures, improves soil fertility through nitrogen increasing to the system and improves forage yield and quality (Francis et al., 1976; Willey, 1979). Many researches have explored the use of intercropping for forage production. Toniolo et al. (1987) reported significantly higher crude protein (CP) content of maize-soybean intercropping than that of monocropped maize. Javanmard et al. (2009), worked on intercropping of maize with different legumes, indicated that dry matter yield and crude protein yield of forage were increased by all intercropping compositions as compared with the maize monoculture. Dahmardeh et al. (2009) concluded that intercropping of maize and cowpea resulted in more digestible dry matter and also crude protein content than maize sole cropping.

Our objectives in this experiment were to evaluate forage production potential of maize and cowpea intercropping in terms of (i) total dry matter production and (ii) maize forage quality. 


\section{Materials and methods}

A field experiment was conducted during the 2007 growing season on a farm at Emmanuel Alayande College of Education, Oyo, Lanlate Campus,(EACOED) Teaching and Research Farm, Lanlate, Southwest Nigeria. Lanlate lies between latitude $7^{0} 30^{\circ} \mathrm{N}$ and Longitude $3^{0} 52 \mathrm{E}$ in the tropical rainforest belt. The experiment was established in a silt loam soil with $\mathrm{pH}$ 7.1. The previous crop was winter wheat which was harvested in May 18, 2006. After that, wheat straw was removed from field. The meteorological data were recorded from sowing date to the harvest of each treatment (Tab. 1.).

Five treatments (two monocultures and three mixtures of maize and cowpea) were included in the experiment as showed in Tab. 2. The experimental design was a randomized complete block (RCB) with three replications.

The intercrop composition was based on the replacement design (Snaydon, 1991), in which one maize plant was replaced by three cowpea plants. Total population of intercrop components were half of their sole crops. The plots size was $15 \mathrm{~m} 2$ consist of six rows of $5 \mathrm{~m}$ long. The rows were located $50 \mathrm{~cm}$ apart. Treatments were separated by a $2 \mathrm{~m}$ buffer zone. The site of experiment was ploughed to $0.2-0.3 \mathrm{~m}$ depth after the removal of winter wheat straw, followed by harrowing prior to drilling the trial. All plots were fertilized with the same amount of fertilizer before sowing, containing $70 \mathrm{~kg}$ of N ha-1, $70 \mathrm{~kg}$ P2O5 ha-1 and $70 \mathrm{~kg}$ of K20 ha- 1 . Maize and cowpea were sown to a depth of approximately 7 and $5 \mathrm{~cm}$ respectively by hand in July 26, 2003. Seed rates of 10 and 38 seeds of maize and cowpea, respectively, per $\mathrm{m} 2$ were sown to allow for thinning down to an approximate plant population of 6.7 and 20 plants per m2. Photosynthetically active radiation (PAR) was measured two times during the growing season (55 and 70 days after sowing) between 12-14 hours on occasions. A Sun fleck ceptometer (model SF-80T) was used to measure above the plant canopy and the soil surface at 5 randomly selected locations within each plot. Mean values for each plot were then used to calculate the percentage of PAR intercepted by plant canopy. The soil water balance was expected to be influenced by different cropping systems. Soil water content at $0-0.25 \mathrm{~m}$ depth was determined on two occasions (55 and 70 days after sowing) during the growing season. Soil samples were taken from three locations within each plot and a well mixed sample was used to determine soil moisture content by gravimetric measurement. Soil temperature was also recorded at a depth of $0-10 \mathrm{~cm}$ below the surface on two occasions in all plots, using a soil thermometer.

Maize and cowpea were harvested simultaneously in a $1 \mathrm{~m} 2$ area of each plot in October 25, 2007. Plants were cut at $2 \mathrm{~cm}$ above the soil surface and separated by hand into maize and cowpea. Plants were dried in the oven at $70{ }^{\circ} \mathrm{C}$ for $48 \mathrm{~h}$ and weighed to record dry matter yield. Total $\mathrm{N}$ of maize in different cropping system was determined, using the Kjeldahl's method and crude protein (CP) was calculated by multiplying the $\mathrm{N}$ content by 6.25 .

The analysis of variance of the data was carried out, using MSTATC software. Treatment mean differences were separated by the least significant difference (LSD) test at 0.05 probability level.

\section{Results and discussions}

Percentage of PAR interception was significantly $(\mathrm{P} \leq 0.05)$ affected by cropping system (Tab. 3$)$. The mean of PAR interception averaged over sampling dates by intercrop treatments and sole cropped cowpea were significantly $(\mathrm{P} \leq 0.05)$ higher than that of sole cropped maize. The mean percentage of PAR interception for the intercrop treatments and cowpea sole crop was similar at 55 days after sowing (DAS) and higher for intercrop treatment at 70 DAS (Tab. 3).

Soil temperature was significantly $(\mathrm{P} \leq 0.05)$ affected by cropping systems. At $55 \mathrm{DAS}$, the soil temperature for intercrop treatments and cowpea sole crop was significantly lower than that of sole cropped maize (Tab. 3). At 70 DAS, soil temperature under intercrop treatments was significantly $(P \leq 0.05)$ lower than for maize and cow pea sole crops.

The moisture content of soil, determined by gravimetric method, was significantly $(P \leq 0.05)$ influenced by cropping system (Tab. 3). Moisture content of soil in sole cropped wheat at two sampling dates was higher than for intercrop treatments and cowpea sole crop. However, there was no significant difference between maize and cowpea sole cropped at 55 DAS.

Dry weights of all three intercrops were significantly $(\mathrm{P} \leq 0.05)$ greater than those of sole crops (Tab. 4) and exceeded the expected yield [(sole cowpea yield + sole maize yield) / 2]. There were no significant differences between intercrops grown with different planting patterns. Maize sole crop produced significantly greater dry weight than cowpea sole crop. The mean dry weight averaged over intercrops was 1.7 and 1.2 times that of sole cow pea and maize, respectively (Tab. 4).

Total nitrogen uptake by maize was significantly $(\mathrm{P} \leq 0.05)$ affected by cropping system (Tab. 5). Nitrogen uptake by maize in intercropping was significantly greater than for sole maize. There were no significant differences betweens intercrops for $\mathrm{N}$ uptake by maize. The mean $\mathrm{N}$ uptake in intercrop plots were 1.34 time that of sole maize plots. 
Crude protein content ( $\mathrm{g} \mathrm{kg}-1$ dry matter) of maize in intercrops was significantly $(\mathrm{P} \leq 0.05)$ greater than in maize sole crop. Crude protein of maize showed no significant differences between different intercrop planting patterns (Tab. 6). Therefore, forage quality of maize was higher in intercrops compared with its sole crop.

Differences in vertical arrangement of foliage and canopy architecture of intercrop components, may lead to more PAR interception by intercropping compared with sole crops (Keating and Carberry., 1993). More PAR interception by different intercropping systems has been rereported (Chand, 1997; Ghanbari-bonjar, 2000; Midmore et al., 1998). PAR interception seems to play a relatively important role in determining total intercrop productivity. High light interception by intercrops caused higher shading and, therefore, lowers soil temperature, which agrees with the finding of Harris and Natarajan (1987) who suggested that the micro climate within the canopy of cropping systems were altered, so that shading reduced canopy temperature. Thus, it seems that percent of light interception by canopies would be a major factor affecting soil temperature.

Intercropping may be more efficient at exploiting a larger total soil volume if component crops have different rooting habits, especially depth of rooting (Ahlawat et al., 1985). Lower soil moisture content in intercrops treatments compared to sole crop could not be due to higher evaporation from the soil surface, because soil temperatures under intercrops were lower than sole crops (tab. 3). One explanation for more water extraction with intercrops could be as a result of more soil exploration by root system of intercrop, resulting in a drier soil profile compared to that for sole crop.

The morphological and physiological differences among intercrop components result in their ability to occupy different niches. Thus, environmental resources could be more efficiently utilized and converted to biomass by mixed stands of crops than by pure stands. Therefore, in the present experiment, more PAR interception and also a greater water extract (Tab. 3) by intercrops could be the major reason for the greater dry weight observed for intercropping over sole cropping. Greater resource use by intercrops was considered as the biological basis for obtaining yield advantages (Willey, 1979; Keating and Carberry, 1993).

The system of intercropping is an important factor which affects the quantity on $\mathrm{N}$ fixed by legumes (Rerkasem et al., 1988). The differences in the depth of rooting, lateral root spread and root densities are some of the factors that affect competition between the component crops in an intercropping system for nutrients. The cereal component, maize in this experiment, usually is taller, has a faster growing or more extensive root system, particularly a larger mass of fine roots and is competitive for soil nitrogen (Carr et al., 1998; Carruthers et al., 2000). This forces the legumes component, cowpea in this experiment, to fix $\mathrm{N}$ from the atmosphere (Jensen, 1996; Huaggaard-Nielson et al, 2001). This is expressed as a facilitative effect of intercrop components, meaning that maize and cowpea have complementary effect in consuming nitrogen. Maize receives its required nitrogen from soil and cowpea from biological fixation of atmospheric $\mathrm{N}$. in intercrops, it prepares maize with more nitrogen, leading to more $\mathrm{N}$ uptake, and therefore, more crude protein of maize in intercropping compared with its sole crop. Thus, forage quality of maize was improved by intercropping due to more nitrogen availability for maize in intercropping.

\section{Conclusions}

Forage dry weights achieved by the intercrops were greater than those by either maize or cowpea sole crops. The results of this experiment could provide some quantitative evidence for the hypothesis that greater environmental resources consumption (such as PAR and soil moisture) by intercrops is a primary cause of yield advantages. Intercropping resulted in higher maize forage quality, because of more $\mathrm{N}$ supply for maize, induced by complementary interaction between maize and cowpea in intercropping for $\mathrm{N}$ consumption.

\section{References}

[1] Ahlawat, I. P., A. Singh and R. P. Sharma (1985). Water and nitrogen management in wheat-lentil intercropping system under late-season condition. Journal of Agricultural Science. 105: 697-701.

[2] Anil, L., j. Park and R. H. Phipps (2000). The potential of forage-maize intercrops in ruminant nutrition. Animal Feed Science and Technology. 85: 157-164.

[3] Carr, P. M., G. B. Martins, J. S. Caton and W. W. Poland (1998). Forage and N yield of barley-pea and oat-pea intercrops. Agronomy Journal. 90:79-84.

[4] Carruthers, K., B. Prithiviraj, O. Fe, D. Cloutler, R. C. Martin and D. L. Smith (2000). Intercropping corn with soybean, lupin and forages: Yield component responses. European Journal of Agronomy. 12:163-115.

[5] Chand, S. P. (1997). Effect of time planting of traditional potato varieties on yield of intercropped potato-maize in the hills of Nepal. PhD thesis. Wye College. University of London.

[6] Cusicanqui, A. and J. G. Lauer (1999). Plant density and hybrid influenced on corn forage yield and quality. Agronomy Journal. 91:911-915.

[7] Dahmardeh, M., A, Ghanbari, B. Syasar and M. Ramroudi (2009). Effect of intercropping maize with cowpea on green forage yield and quality evaluation. Asian Journal of Plant Science. 8(3):235-239.

[8] Francis, C. A., C. A. Flor and S. R. Temple (1976). Adapting varieties for intercropping systems in the tropics. In: Papendick R. I., P. A. Sanches and G. B. Triplett. (eds). Multiple cropping. Special publication number 27. Pp. 235-253. Madison. American Society of Agronomy.

[9] Ghanbari-Bonjar. A. (2000). Intercropped wheat and bean as a low-input forage. PhD thesis. Wye College. University of London. 
[10] Hauggaard-Nieson, H., P.Ambus and E. S. Jensen (2001). Temporal and spatial distribution of roots and competition for nitrogen in pea-barley intercrops. A field studies employing 23 P techniques. Plant and Soil. 236:63-74.

[11] Javanmard, A., A. Dabbagh Mohammadi-Nasab, A. Javanshir, M. Moghaddam and H. Janmohammadi (2009). Forage yield and quality in intercropping of maize with different legumes as double-cropped. Journal of Food, Agriculture and Environment. 7(1):163-166.

[12] Jensen, E. S. (1996). Grain yield, symbiotic N2 fixation and interspecific competition for inorganic N in pea-barley intercrops. Plant and Soil. 182(1): 25-38.

[13] Keating, B. and P. Carberry (1993). Resource capture and use in intercropping: Solar radiation. Field Crops Research. 34: 273301.

[14] Lawes, D. A. and D. I. H. Jones (1971). Yield, nutritive value and ensiling characteristics of whole-crop spring cereals. Journal of Agricultural Science. 76:497-485.

[15] Midmore, D. J., J. Raco and D. Berrios (1988). Potato in hot tropics. IV. Intercropping with maize and the influence of shade on potato micro-environment and crop growth. Field Crops Research. 18:141-157.

[16] Ofori, F. and W. R. Stern (1987). Cereal-legume intercropping systems. Advance in Agronomy. 41:41-90.

[17] Rerkasem, B., K. Rerkasem, M. B. Peoples, B. F. Herrigde and F. J. Bergersen (1998). Measurement of N2 fixation in maizerice bean intercrops. Plant and Soil. 108:125-135.

[18] Snaydon, R. W. (1991). Replacement and additive designs for competition studies \. Journal of Applied Ecology. 28: 934-946.

[19] Toniolo, L., M. Sattin and G. Mosca (1987). Soyabean-maize intercropping for forage. Eurosoya. 5:73-78.

[20] Willey, R. W. (1979). Intercropping: its importance and research needs. Part П. Agronomy and research approaches. Field Crops Research. 32: 1-10.

Table 1. Meteorological data for maize-cowpea intercropping area in 2007

$\begin{array}{lllll}\text { Month } & \text { Minimum temp }\left({ }^{\circ} \mathrm{C}\right) & \text { Maximum temp }\left({ }^{\circ} \mathrm{C}\right) & \text { Relative humidity }(\%) & \text { Rainfall }(\mathrm{mm}) \\ \text { July } & 31 & 46 & 26 & \mathrm{NR} \\ \text { August } & 27.2 & 43.2 & 20 & \mathrm{NR} \\ \text { September } & 24.3 & 39.3 & 24 & \mathrm{NR} \\ \text { October } & 16.6 & 29.4 & 34 & 1.4\end{array}$

NR: no rainfall

Table 2. The description of experimental treatments

$\begin{array}{ll}\text { Treatment } & \text { Description } \\ \text { Cp } & \text { Sole cowpea } \\ \text { C } & \text { Sole maize } \\ \text { M1 } & \text { Alternate-row intercrop } \\ \text { M2 } & \text { Within-row intercrop } \\ \text { M3 } & \text { Mixed intercrop }\end{array}$

Table 3. Effect of different cropping system on PAR interception, soil temperature and soil moisture content

$\begin{array}{llllllll}\begin{array}{l}\text { Cropping } \\ \text { system }\end{array} & \begin{array}{l}\text { PAR } \\ (\%)\end{array} & \text { interception } & \begin{array}{l}\text { Soil } \\ \left({ }^{\circ} \mathrm{C}\right)\end{array} & \text { temperature } & \begin{array}{l}\text { Soil } \\ (\%)\end{array} & \text { moisture } & \text { content } \\ \text { Cp } & \text { 55 DAS 70 DAS } & \text { 55DAS } & \text { 70DAS } & \text { 55 DAS 70 DAS } & \\ \text { M1 } & 63.8 \mathrm{a} & 71.3 \mathrm{~b} & 28.0 \mathrm{a} & 28.9 \mathrm{~b} & 15.9 \mathrm{~b} & 71.3 \mathrm{~b} & \\ \text { M2 } & 69.4 \mathrm{a} & 98.2 \mathrm{a} & 28.3 \mathrm{a} & 27.6 \mathrm{a} & 9.4 \mathrm{a} & 98.2 \mathrm{a} & \\ \text { M3 } & 66.4 \mathrm{a} & 97.5 \mathrm{a} & 27.9 \mathrm{a} & 27.5 \mathrm{a} & 11.5 \mathrm{a} & 97.5 \mathrm{a} & \\ \mathrm{C} & 64.2 \mathrm{a} & 97.1 \mathrm{a} & 27.1 \mathrm{a} & 26.5 \mathrm{a} & 12.2 \mathrm{a} & 97.1 \mathrm{a} & \\ \text { LSD at } 0.05 \% & 7.30 & 2.90 & 30.5 \mathrm{~b} & 30.0 \mathrm{~b} & 16.8 \mathrm{~b} & 62.1 \mathrm{c} & \end{array}$

Different letters in each column indicate significance at $P \leq 0.05$; Cp: sole cow pea; M1: alternate-row intercrop; M2: within-row intercrop; M3: mixed intercrop; $C$ : sole maize 
Table 4. Effect of different cropping system on forage yield (t.ha-1)

$\begin{array}{ll}\text { Cropping system } & \text { Forage } \\ \text { Cp } & 6.13 \mathrm{c} \\ \text { M1 } & 10.47 \mathrm{a} \\ \text { M2 } & 11.13 \mathrm{a} \\ \text { M3 } & 10.16 \mathrm{a} \\ \text { C } & 8.7 \mathrm{~b} \\ \text { LSD at } 0.05 \% & 1.44\end{array}$

Different letters indicate significance at $P \leq 0.0 \mathrm{Cp}$ : sole cow pea; M1: alternate-row intercrop; M2: within-row intercrop; M3: mixed intercrop; $C$ : sole maize

Table 5. Nitrogen uptake (kg. ha-1) by maize in different cropping system

Cropping system Nitrogen uptake

C $12.16 \mathrm{~b}$

M1 $16.16 \mathrm{a}$

M2 16.39a

M3 $16.03 \mathrm{a}$

LSD at $0.05 \%$

Different letters indicate significance at $P \leq 0.05$ C: sole maize; M1: alternate-row intercrop; M2: within-row intercrop; M3: mixed intercrop

Table 6. Crude protein content (g.kg -1 dry matter) of maize in different cropping system Cropping system Crude protein

$\mathrm{C} \quad 76 \mathrm{~b}$

M1 $101 \mathrm{a}$

M2 $102.38 \mathrm{a}$

M3 $100.19 \mathrm{a}$

LSD at $0.05 \%$

Different letters indicate significance at $P \leq 0.05$ C: sole maize; M1: alternate-row intercrop; M2: within-row intercrop; M3: mixed intercrop

\begin{abstract}
About Authors
Abdulraheem, Mukhtar Iderawumi is the Farm Manager, Department of Agricultural Education, Emmanuel Alayande College of Education, Oyo, Lanlate Campus, Lanlate, Oyo State, Nigeria; Professor Steven Olusola Ojeniyi is a Professor of Soil Fertility at the Federal University of Technology, Akure, Nigeria and the current Editor-in-Chief of Nigerian Journal of Soil Science while Charles, Eneminyene Friday is currently an Assistant Chief Agricultural Superintendent at the Nigeria Institutes for Oil Palm Research, Benin City, Edo State, Nigeria
\end{abstract}

